\title{
ZELENA KNJIŽNICA FILOZOFSKOG FAKULTETA SVEUČILIŠTA U ZAGREBU
}

\author{
THE GREEN LIBRARY OF THE FACULTY \\ OF HUMANITIES AND SOCIAL SCIENCES IN ZAGREB
}

\author{
Lana Zrnić \\ Filozofski fakultet, Knjižnica \\ Sveučilište u Zagrebu \\ 1zrnic@ffzg.hr \\ Elvira Gotal \\ Filozofski fakultet, Knjižnica \\ Sveučilište u Zagrebu \\ egotal@ffzg.hr \\ Jasmina Sočo \\ Filozofski fakultet, Knjižnica \\ Sveučilište u Zagrebu \\ jsoco@ffzg.hr \\ Blaženka Klemar Bubić \\ Filozofski fakultet, Knjižnica \\ Sveučilište u Zagrebu \\ bklemar@ffzg.hr
}

UDK / UDC: 027.7:502/504"2018/2021"(497.5 Zagreb)

Stručni rad / Professional paper

Primljeno / Received: 31. 3. 2021.

Prihvaćeno / Accepted: 23. 8. 2021.

\section{Sažetak}

Cilj. Cilj je rada upoznati javnost, ponajprije knjižničarsku zajednicu, s programima Zelene knjižnice Filozofskog fakulteta u Zagrebu, realiziranima od 2018. do 2021. go-

Vjesnik bibliotekara Hrvatske 64, 2(2021), 425-442

ISSN 0507-1925 
dine, koji ističu važnost usvajanja vještina i znanja o ekološkoj tematici radi podizanja svijesti o važnosti zaštite okoliša i održivom razvoju te promidžbe među korisnicima Knjižnice Filozofskog fakulteta u Zagrebu.

Pristup. U ovom će se radu obrazložiti teorijska i praktična primjena programa namijenjenih zaštiti okoliša i poticanja održivog razvoja društva u visokoškolskoj knjižnici, Knjižnici Filozofskog fakulteta u Zagrebu i razmotriti kako se mogu uklopiti u programe drugih visokoškolskih knjižnica i fakulteta.

Rezultati. U radu su prikazani različiti načini obrazovanja korisnika knjižnice o važnosti održivog razvoja i zaštiti okoliša od ožujka 2018. do ožujka 2021. godine. Rad je prepoznat i u stručnim, međunarodnim krugovima: Knjižnica Filozofskog fakulteta u Zagrebu prva je hrvatska knjižnica označena na IFLA-inoj stranici SDG Stories Map IFLA Map of the World.

Praktična primjena. Zelena knjižnica Filozofskog fakulteta organizira aktivnosti usmjerene zaštiti okoliša i poticanja održivog razvoja društva, namijenjene prvenstveno vlastitim korisnicima, ali i široj javnosti. Programi studija Filozofskog fakulteta pružaju brojne mogućnosti uklapanja zelenih tema u obliku otvorene nastave u smislu suradnje sa znanstvenim, nastavnim i nenastavnim osobljem Fakulteta, kao i sa znanstvenicima $\mathrm{s}$ drugih institucija i fakulteta te $\mathrm{s}$ drugim ustanovama i udrugama koje se bave srodnim temama.

Društveni značaj. Cilj je svih aktivnosti širenje svijesti o održivom razvoju i društvu jer poticanje i osvještavanje problema vezanih uz zelene teme utječu na osobni razvoj sudionika programa podižući svijest o nužnosti zaštite okoliša. Uska suradnja knjižničara, profesora, studenata i vanjskih suradnika omogućuje bržu i kvalitetniju implementaciju saznanja u svakodnevni život. Održane aktivnosti Zelene knjižnice Filozofskog fakulteta mogu potaknuti druge knjižnice kako implementirati zelene teme u programe korisne lokalnoj zajednici.

Originalnost. Originalnost programa Zelene knjižnice Filozofskog fakulteta proizlazi iz želje da se na Filozofskom fakultetu, koji je društveno-humanističkog usmjerenja, prepozna potencijal zelenih tema, koje su most su između društvenih i prirodnih znanosti, čime je stavljen naglasak na to koliko je čovjek povezan s prirodom kroz vjerovanja, običaje, književnost i jezik.

Ključne riječi: Filozofski fakultet Zagreb, međuinstitucijska suradnja, održivi razvoj, visokoškolska knjižnica, zaštita okoliša, zelena knjižnica

\section{Abstract}

Goal. The aim of the paper is to acquaint the general public, and especially the library community, with the programs of the Green Library of the Faculty of Humanities and Social Sciences in Zagreb, realized in the period from 2018 to 2021. The programs empha- 
size the importance of acquiring skills and knowledge on environmental issues through developing awareness of environmental protection and sustainable development.

Approach. This paper will explain the theoretical and practical application of green programs in academic libraries on the example of the Library of the Faculty of Humanities and Social Sciences in Zagreb. Furthermore, it will analyze the ways in which the programs designed to protect the environment and promote sustainable development of society can be implemented into programs of other higher education and academic libraries.

Results. The paper presents different ways of educating users about the importance of sustainable development and environmental protection in the period from March 2018 to March 2021. The work of the Faculty Green library is also recognized in the international professional community: the Library of the Faculty of Humanities and Social Sciences in Zagreb is the first Croatian library marked on IFLA's page SDG Stories Map - IFLA Map of the World.

Practical use. The Green Library of the Faculty of Humanities and Social Sciences organizes activities aimed at protecting the environment and encouraging the sustainable development of society. The study programs of the Faculty of Humanities and Social Sciences provide numerous opportunities to include the green topics in the form of open teaching in cooperation with the scientific, teaching, and non-teaching staff of the Faculty, as well as with the scientists from other institutions and faculties, and with other institutions and associations dealing with related topics.

Social significance. The goal of all these activities is to increase awareness about sustainable development and society. Encouraging and raising awareness of issues related to green topics affect the personal development of program participants by raising awareness of the necessity to protect the environment. Close cooperation between librarians, professors, students and external associates enables faster and better implementation of this knowledge in everyday life. The activities of the Green Library of the Faculty of Humanities and Social Sciences can encourage other libraries to implement green topics in the new programs useful to the local community.

Originality. The originality of the Green Library program of the Faculty of Humanities and Social Sciences, which has a social and humanistic orientation, originates from the desire to recognize the enormous potential of green topics. Green themes represent a bridge between the social and natural sciences. They are connected in a unique way in a socio-humanistic context, thus emphasizing to what extent man is connected to nature through beliefs, customs, literature, and language.

Keywords: academic library, environmental protection, Faculty of Humanities and Social Sciences Zagreb, green library, inter-institutional cooperation, sustainable development 


\section{Uvod}

Rad se temelji na zamisli koju je u ožujku 2018. pokrenula grupa knjižničarki Knjižnice Filozofskog fakulteta Sveučilišta u Zagrebu. Osluškujući potrebe društvene zajednice, kao i stručne smjernice za razvoj svojih usluga, pridružila se knjižnicama koje u sklopu svoje redovne djelatnosti obrazuju korisnike, ali i javnost, o zaštiti okoliša i održivom razvoju.

Korisnici Knjižnice Filozofskog fakulteta u prvom su redu studenti te znanstveno, nastavno i nenastavno osoblje Fakulteta. Filozofski fakultet godišnje upisuje oko 1000 novih studenata koji su aktivni društveni potencijal. Događanja koja Knjižnica i Fakultet organiziraju otvorena su za sve korisnike kako studente tako i djelatnike Fakulteta, ali i ostalu zainteresiranu publiku.

Organizirajući predavanja, izložbe i prikazivanje dokumentarnih filmova tematski vezanih uz ekologiju i održivi razvoj, a stavljajući naglasak na povezanost čovjeka i prirode kroz vjerovanja, običaje, književnost i jezik, povezujemo društvene i prirodne znanosti.

Filozofski je fakultet visokoškolska ustanova s tridesetak društveno-humanističkih studija i, osim profesionalnog usmjerenja i obrazovanja, može ponuditi teorijsko i praktično znanje o održivom razvoju. Koncept održivog razvoja trebao bi postati okvir za sva buduća gospodarska, ekonomska i politička rješenja. Zbog toga je nužno implementirati ga u obrazovanje. Da bi naše društvo imalo budućnost, mora stasati u okviru tih tema, a one se idealno mogu predstaviti u knjižnicama. Na jednom je mjestu objedinjena ponuda informacija, ljudskih resursa, tehnologije i prostora, što olakšava promicanje ideja održivog razvoja. Naglašavajući aktualna pitanja, knjižnica ispunjava svoju društvenu odgovornost i korisna je lokalnoj zajednici. ${ }^{1}$

Ekologija i teme koje uključuju održivi razvoj važne su za pojedinca i zajednicu te bi trebale postati osnovni i bitan dio obrazovanja svakog čovjeka. Na akademskoj razini takvo obrazovanje može ponuditi visokoškolska knjižnica. U Zakonu o knjižnicama navodi se svrha osnivanja visokoškolskih knjižnica:

„Visokoškolske knjižnice osnivaju se radi svrhovita prikupljanja, stručne obrade, pohrane/arhiviranja i osiguravanja pristupa tiskanoj i elektroničkoj građi, elektroničkim bazama podataka i mrežnim informacijskim izvorima namijenjenih studentima, nastavnicima, stručnim suradnicima visokih učilišta, ali i ostalim članovima šire društvene zajednice. Visokoškolska knjižnica pruža podršku obra-

1 Čadovska, I.; A. Tkalčić. Zelena pismenost kao dio strategije razvoja informacijske službe. // Vjesnik bibliotekara Hrvatske 60, 1(2017), str. 70. DOI: http://doi.org/10.30754/vbh.60.1.537. 
zovnom, znanstvenom i javnom djelovanju osnivača, odnosno matične ustanove."2

Aktualizacija zelenih tema proširuje informacijske potrebe korisnika Knjižnice Filozofskog fakulteta, a raznovrsnost studijskih grupa omogućuje njihovo uklapanje u studijske programe. Istovremeno, zbog otvorenosti prema ostalim korisnicima šire društvene zajednice, ima mogućnost i ulogu u javnom djelovanju. Zelene teme naglašavaju ulogu i uključenost visokoškolske knjižnice u aktivnosti zajednice.

\section{Zelena knjižnica}

Pojam zelena knjižnica može imati dvostruko značenje. Aulisio je ponudio dva značenja, prvo značenje odnosi se na zgradu knjižnice koja u najmanjoj mogućoj mjeri onečišćuje okoliš, građena je energetski učinkovito i koristi obnovljive izvore energije te savjesno gospodari otpadom. Drugo značenje odnosi se na knjižnicu koja promovira održivost kroz obrazovanje i aktivnosti. „Prava“ zelena knjižnica je ona koja je uključila održivost u segmente knjižničnog poslovanja. ${ }^{3}$

Pojmom zelenih knjižnica i preduvjetima koje knjižnice moraju ostvariti kako bi se smatrale zelenima te njihovim kategorizacijama bavi se posebna grupa unutar Međunarodne federacije knjižničarskih društava i ustanova (International Federation of Library Associations and Institutions - IFLA) pod nazivom Grupa za okoliš, održivost i knjižnice (Environment, Sustainability and Libraries Special Interest Group - ENSULIB). ${ }^{4}$ Knjižnice mogu pridonijeti povećanju svijesti o održivosti, stoga ta Grupa radom želi potaknuti knjižničare diljem svijeta na razmišljanje o učinku klimatskih promjena na knjižnice (promjena uvjeta čuvanja knjiga, izolacija zgrada, i dr.), o primjeni ekoloških praksi u samoj knjižnici (recikliranje papira, korištenje obnovljivih izvora energije, razvrstavanje otpada, i dr.), uslugama i aktivnostima vezanima uz održivost (izložbe, informiranje članova knjižnice, razvoj zbirki vezanih uz teme zaštite i očuvanja okoliša), povećanju svijesti knjižničara o problemima zaštite okoliša, te da u skladu s tim organiziraju svoje programe i aktivnosti. U svom članku, Edita Bačić navodi:

"Kroz osmišljene programe potrebno je utjecati na podizanje svijesti o važnosti javnog zagovaranja kod pripadnika profesionalne zajednice i donosilaca odluka, da prepoznaju knjižnice ne samo kao

\footnotetext{
2 Čl. 5 Zakona o knjižnicama. Usp. Zakon o knjižnicama. // Narodne novine 17, 356(2019). [citirano: 2021-3-3]. Dostupno na: https://narodne-novine.nn.hr/clanci/sluzbeni/2019_02_17 356 . html.

3 Aulisio, G. J. Green libraries are more than just buildings. // Electronic Green Journal 35, 1(2013), str. 2. [citirano: 2021-02-03]. Dostupno na: http://escholarship.org/uc/item/3x11862z.

4 IFLA. Environment, sustainability and libraries section (ENSULIB). [citirano: 2021-03-19]. Dostupno na: https://www.ifla.org/environment-sustainability-and-libraries.
} 
mjesta važna za kulturu i učenje već i kao odgovorne i nezaobilazne partnere u razvoju društva općenito. Promatrano u globalnim okvirima, danas je to vrlo važno i s gledišta zagovaranja uloge knjižnica u implementaciji ciljeva UN-ove Agende 2030 za koju se zalaže cijela međunarodna zajednica, uključujući i Republiku Hrvatsku."

Međunarodne ciljeve koji su osmišljeni za globalnu dobrobit društva važno je implementirati u obrazovanje. Knjižnice su prepoznate kao mjesta koja mogu značajno doprinijeti širenju i provođenju strategije održivosti te je važno da i visokoškolske knjižnice podrže tu inicijativu.

\section{Zelena knjižnica u Hrvatskoj}

Prateći trendove inozemnih i hrvatskih knjižnica, Zelena knjižnica u Hrvatskoj pojavila se 2011. godine u Istarskoj županiji kao projekt Društva bibliotekara Istre. Nakon 38. skupštine Hrvatskog knjižničarskog društva ${ }^{6} 2012$. godine u Osijeku počele su se uključivati i druge knjižnice, pa se tako na idućoj, 39. skupštini Hrvatskog knjižničarskog društva ${ }^{7}, 2014$. godine u Splitu, oblikuje Radna grupa za zelene knjižnice pri Sekciji za upravljanje i tehnologiju Hrvatskog knjižničarskog društva. Radna grupa oblikovana je po uzoru na istarski model, ali na nacionalnoj razini, kako bi se mogao uključiti što veći broj knjižnica. ${ }^{8}$ Knjižnica Filozofskog fakulteta uključuje se u postojeću mrežu 2018. godine proširujući svoje primarne zadaće visokoškolske knjižnice aktivnostima vezanima uz ekološku tematiku i održivi razvoj.

\subsection{Zelena knjižnica Filozofskog fakulteta}

Programi koje provodi Knjižnica Filozofskog fakulteta u Zagrebu obilježavajući međunarodne dane vezane uz ekologiju potiču zelenu pismenost (obrazovanje za održivi razvoj), odnosno razumijevanje ljudskog djelovanja na okoliš putem širenja svijesti o održivom razvoju te poticanju kritičkog mišljenja. ${ }^{9}$ Predavanja, radionice, projekcije filmova, predstavljanje knjiga, izložbe i tribine potiču diskusiju i senzibiliziraju javnost te je istovremeno informiraju o održivom razvo-

\footnotetext{
5 Bačić, E. Zagovaranje za knjižnice i partnerstvo za održivi razvoj. // Vjesnik bibliotekara Hrvatske 61, 2(2018), str. 378. DOI: http://doi.org/10.30754/vbh.61.2.707.

6 Hrvatsko knjižničarsko društvo. 38. skupština Hrvatskoga knjižničarskog društva. [citirano: 2021-03-06] Dostupno na: https://www.hkdrustvo.hr/hr/skupovi/skup/198.

7 Hrvatsko knjižničarsko društvo. 39. skupština Hrvatskoga knjižničarskog društva. [citirano: 2021-03-06] Dostupno na: https://hkdrustvo.hr/hr/skupovi/skup/241.

8 Kraljević, I. Djelovanje Radne grupe za zelene knjižnice 2014.-2018. // Vjesnik bibliotekara Hrvatske 62, 1(2019), str. 330. DOI: http://doi.org/10.30754/vbh.62.1.720.

9 Čadovska, I.; Tkalčić, A. Nav. dj., str. 65.
} 
ju, zaštiti okoliša i utjecajima ekoloških tema na svakodnevicu. Prepoznavanje važnosti koncepta održivog razvoja zajednice podrazumijeva ravnotežu društva, okoliša i gospodarstva te se sukladno Strategiji održivog razvitka obrazovanje treba provoditi na tri razine: formalno obrazovanje, neformalno obrazovanje izvan uobičajenih obrazovnih ustanova te obrazovanje putem medija. Interdisciplinarnim prožimanjem tih triju razina, obrazovanje se uključuje u svakodnevni život i postaje temelj održivosti. ${ }^{10}$

U planiranim i provedenim programima osnovno polazište temelji se na suradnji. Ona uključuje suradnju s nastavnicima na Fakultetu, stručnjacima izvan Fakulteta, studentima i pojedinim građanskim grupama, na što, uostalom, poziva i Vijeće Europe 2012. u svojim zaključcima o upravljanju kulturom kao partnerstvom kulturnih ustanova i civilnog društva. ${ }^{11}$ Globalni ciljevi održivog razvoja Ujedinjenih naroda (Agenda 2030) također spominju učinkovito upravljanje kao temelj održivog razvoja. ${ }^{12}$ Takvim pristupom trudimo se još više uključiti Knjižnicu u nastavni plan i program, ali i proširiti njezin utjecaj na zajednicu. Obrazovanje se provodi u suradnji sa znanstvenim, nastavnim i nenastavnim osobljem Fakulteta, kao i sa znanstvenicima s drugih fakulteta i institucija, te u suradnji s ustanovama i udrugama koje se bave srodnim temama. Obilježavajući neke od međunarodnih dana vezanih uz ekologiju, kroz predavanja i radionice, projekcije filmova, predstavljanja knjiga, izložbe, tribine i sl., želimo senzibilizirati korisnike i informirati o održivom razvoju, zaštiti okoliša i utjecajima ekoloških tema i pitanja na svakodnevni život zajednice i pojedinca kao i prepoznavanje važnosti koncepta održivog razvoja zajednice koji podrazumijeva ravnotežu društva, okoliša i gospodarstva.

\subsubsection{Aktivnosti Zelene knjižnice Filozofskog fakulteta u Zagrebu}

Aktivnosti Zelene knjižnice Filozofskog fakulteta zamišljene su kao suradnja Filozofskog fakulteta sa srodnim obrazovnim institucijama, udrugama ili pojedincima koji se bave zelenim temama. Osim što aktivno sudjeluje u obrazovanju o zelenim temama, knjižnica se i u praksi trudi biti „zelena“.

Od otvorenja nove Knjižnice 2009. godine na svakom katu i u svakom uredu nalaze se spremnici za prikupljanje papira s osiguranim odvozom. U Knjižnici su

10 Strategija održivog razvitka Republike Hrvatske. // Narodne novine 30, 658(2009). [citirano: 2021-05-20]. Dostupno na: na http://narodne-novine.nn.hr/clanci/sluzbeni/2009_03_30_658. html.

11 Usp. Council conclusions of 26 November 2012 on Cultural Governance. // Official Journal of European Union 393(2012), str. 9. [citirano: 2021-03-10]. Dostupno na: https://eur-lex.europa.eu/legal-content/EN/TXT/PDF/?uri=CELEX:52012XG1219(03)\&from=EN. 12 UN. Transforming our world: The 2030 agenda for sustainable development, 2015. Str. 11 [citirano: 2021-03-10].

Dostupno na: https://www.un.org/ga/search/view_doc.asp?symbol=A/RES/70/1\&Lang=E. 
četiri čajne kuhinje tako da zaposlenici mogu čuvati i konzumirati vlastitu hranu. Uz spremnike za vodu koji se nalaze na svakom katu u proteklih nekoliko godina ne koriste se plastične čaše.

Od ožujka 2018. godine u Knjižnici postoje spremnici za prikupljanje plastičnih čepova te tako korisnici sudjeluju u akciji „Plastičnim čepovima do skupih lijekova“. Prikupljeni čepovi šalju se Udruzi oboljelih od leukemije i limfoma Hrvatske (UOLL) koja njihovom prodajom kupuje lijekove za oboljele od leukemije i limfoma.

Filozofski fakultet 2018. godine za organizaciju vježbanja u Knjižnici na mini trampolinima dobio je nagradu \#BeCROactive za najaktivnije radno mjesto. ${ }^{13} \mathrm{Za}$ poslenici su se mogli baviti tjelesnom aktivnošću i tako podići svijest o važnosti tjelesne aktivnosti za zdravlje. Novčanu nagradu Državnog ureda za sport Fakultet je iskoristio za nabavu opreme za vježbanje (podloge za vježbanje, trake, lopte, i dr.), a od veljače 2019. pod vodstvom trenerica i kolegica knjižničarki (ujedno i instruktorica fitnesa) redovito se provode ,aktivne pauze“ - dva puta tjedno tijekom 30 minuta za sve zaposlenike Fakulteta.

U nastavku poglavlja navedene su aktivnosti organizirane u Knjižnici od ožujka 2018. do ožujka 2021. godine. Svakoj aktivnosti prisustvovalo je između 50 i 70 posjetitelja, uglavnom studenata, nastavnika i knjižničara, što je otprilike 500 posjetitelja. Brojke se odnose na predavanja i projekcije dokumentarnih filmova. Broj posjetitelja izložbi nije moguće odrediti jer su postavljene u predvorju, u otvorenom pristupu, gdje se protok ljudi ne nadzire.

\subsubsection{Svjetski dan voda}

Ciklus zelenih tema u Knjižnici Filozofskog fakulteta započeo je obilježavanjem Svjetskog dana voda, 22. ožujka 2018. godine. Tim povodom organiziran je skup „Voda - izvor znanja“. Tematski povezana predavanja pokušala su zbližiti društveno-humanističke znanosti i poglede na temu vode s prirodoslovnim znanostima. Teme koje su studentima dobro poznate nadopunjene su prirodoslovnim istraživanjima i pogledima na temu vode. Zbog interdisciplinarnog pristupa nastali su novi uvidi i moguće suradnje među sudionicima skupa. (slika 1)

13 Europski tjedan sporta. [citirano: 2021-03-19]. Dostupno na: https://europski-tjedan-sporta. $\mathrm{hr} /$ dodijeljene-becroactive-nagrade-i-svecano-uruceni-ugovori-za-projekte-financirane-iz-europskog-socijalnog-fonda. 


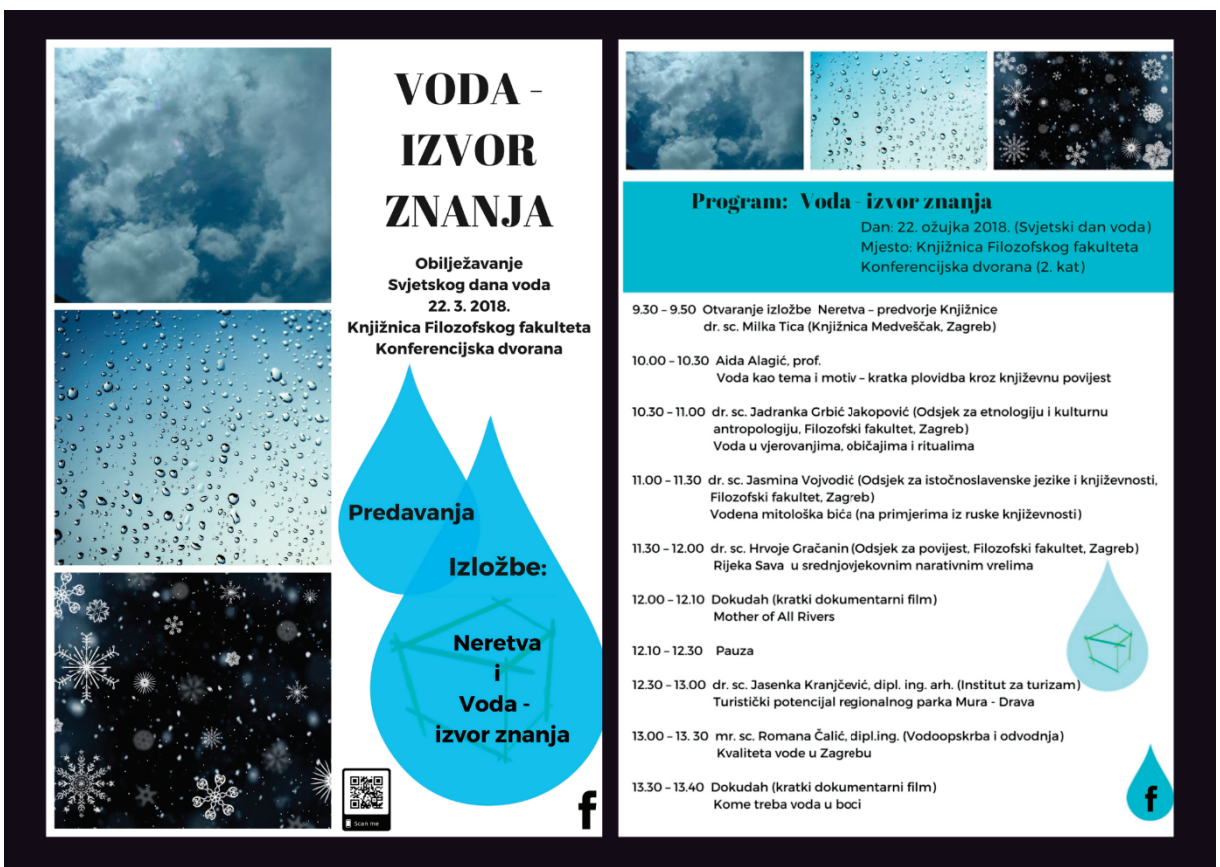

Slika 1. Plakat i program skupa „Voda - izvor znanja“

U prvom bloku predavanja, predavači su bili nastavnici i doktorandi s Filozofskog fakulteta i u svojim su izlaganjima govorili o vodi kao temi i motivu u književnosti od Starog zavjeta do današnjih dana: o vodi kao početku svijeta, Erosu i Tanatosu, blagoslovu i prokletstvu, vodi kao granici i prepreci, o mistici vode, prijetnji, čežnji, izazovu, putu. Bilo je riječi i o vodi u narodnim vjerovanjima, godišnjim običajima i ritualima, o vodenim mitološkim bićima s posebnim naglaskom na primjere iz ruske mitologije i književnosti. Bilo je riječi i o ulozi rijeke Save u srednjem vijeku.

U drugom bloku predavanja riječ su imali gostujući predavači. U izlaganju o projektu Instituta za turizam saznali smo o turističkom potencijalu regionalnog parka Mura - Drava, o vodi i krajoliku uz vodu kao prirodnoj osnovi za razvoj rekreativnog, zdravstvenog, ruralnog i lovnog turizma. Predavanje u suradnji s Vodoopskrbom i odvodnjom dalo je prikaz o kvaliteti vode u Zagrebu.

U suradnji s Mrežom Zelenih knjižnica i udrugom Zelena akcija, koja zainteresiranim hrvatskim knjižnicama omogućuje besplatne projekcije filmova s E-Okolišnog filmskog festivala, ${ }^{14}$ prikazali smo dva dokumentarna filma. Odabrani filmovi tematski su naglasili blokove predavanja. Prvi, Mother of all Rivers, priča

14 Okolišni filmski festival. [citirano: 2021-03-19]. Dostupno na: https://okolisnifestival.zelena-akcija.hr/o-festivalu. 
je o aktivistici Berti Caceres koja svojom aktivnošću unutar lokalne zajednice pobjeđuje vlast i bogatu tvrtku. Berta Caceres dobitnica je Goldman Environmental nagrade, tzv. Zelenog Nobela. Film ilustrira koliko je aktivizam „običnih“ osoba važan i nužan.

Za kraj prikazan je film Kome treba voda u boci. Taj je film naglasio predavanje održano o kvaliteti vode u Zagrebu. Flaširanje vode posao je koji uvijek ima sigurno tržište. Npr. u Hrvatskoj najvećem proizvođaču flaširane vode taj posao donosi dobit od čak 13,5 \%, dok društvu plasira ogromne količine otpada i vodu u boci koja je oko 1000 puta skuplja od zdravstveno ispravne vode iz javne vodoopskrbe.

Taj su dan otvorene i dvije izložbe. Gostujuća izložba pod nazivom „Neretva“ kolegice Milke Tice iz Knjižnice Medveščak tematski je vezana uz povijest Neretvanske doline i prikazuje ulogu rijeke u životu tamošnjeg stanovništva.

Druga izložba sastojala se od dviju manjih izložbi kako bi se naglasila dvostruka uloga vode: voda kao stvaratelj (Voda u knjizi) te voda kao razaratelj (Knjiga u vodi). Na izložbi „Voda u knjizi“ saznali smo zanimljive činjenice o pozitivnoj i nadahnjujućoj ulozi vode - od vode u povijesti, podvodnoj arheologiji, ulozi vode kroz povijest, ekološkim temama vezanim uz vodu do vode kao motivu u književnosti i umjetnosti.

Izložba „Knjiga u vodi“ pokazala nam je destruktivnu snagu vode: veliku poplavu u Zagrebu 1964., kada je poplavljen i Filozofski fakultet, razmjere te poplave i posljedice na knjižničnu građu Fakulteta. Izložba je nadopunjena IFLA-inim smjernicama za pripravnost i planiranje mjera zaštite u slučaju poplave te izborom fraza o vodi u hrvatskom jeziku.

\subsubsection{Dan planeta Zemlje}

Dan planeta Zemlje obilježava se 22. 4., a 2018. godine tema je bila zagađenje plastikom i njezin utjecaj na okoliš.

U sklopu svojih aktivnosti Zelena knjižnica Filozofskog fakulteta povodom tog dana u prizemlju Knjižnice Filozofskog fakulteta organizirala je izložbu pod nazivom „Put plastike“.

Izložba je ukratko dala pregled reciklažnih oznaka u obliku trokuta, tj. u obliku Möbiusove petlje. Znak je pobijedio na natječaju prigodom Dana planeta Zemlje 1970. godine i temelji se na tri načela: načelu smanjivanja, recikliranja i ponovne prerade, čime se spaja i zatvara reciklažni krug i djelotvorno utječe na smanjenje plastičnih zagađivača. S obzirom na to da je vrijeme razgradnje plastičnih materijala od 100 do 1000 godina, važno je osvijestiti okolinu o potrebi recikliranja i ponovne uporabe (slika 2). 


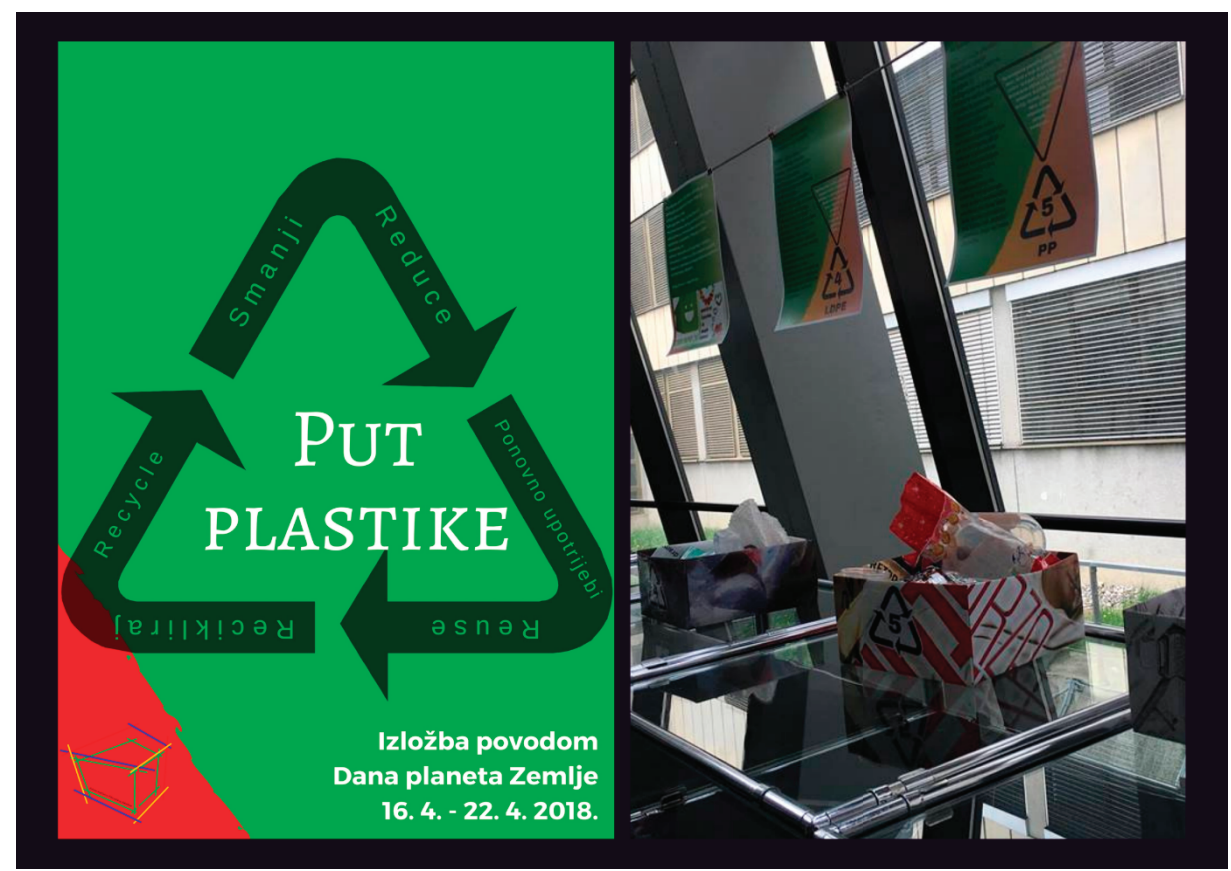

Slika 2. Plakat i fotografija s izložbe „Put plastike“

Predstavljeni plakati opisali su međunarodne oznake za različite vrste plastičnih materijala koji se mogu reciklirati. Slovna je skraćenica oznaka kemijskog spoja od kojeg je ambalaža načinjena, dok se unutar petlje nalazi i proizvoljno dogovorena brojčana oznaka. Izložbom se htjela naglasiti razlika između sigurne i rizične plastike te podučiti o pravilnom recikliranju i vrstama plastike kako bi se neki predmeti iznova rabili bez gomilanja.

Izložba je postavljena interaktivno. U vitrinama te $u$ kutijama na vitrinama postavljen je očišćeni plastični otpad. Ispod svakog plakata s oznakom i ukratko izloženim svojstvima postavljena je kutija u koju su studenti mogli odložiti ponuđenu plastiku prateći oznake na plastici, na kutiji i na informativnom plakatu.

Ta je izložba ujedno obilježila akciju prikupljanja plastičnih čepova u koju smo se uključili preko Udruge Stari Papir „Za Novi Osmijeh“. Humanitarna se akcija provodi od 2012. godine i u nju su uključene brojne osnovne škole, dječji vrtići, ustanove i pojedinci. Prikupljeni čepovi dostavljaju se Udruzi oboljelih od leukemije i limfoma Hrvatske iz Čakovca, koja prodajom otpadnih čepova i poklopaca kupuje lijekove neophodne za liječenje oboljelih. Tako smo se opet uključili u širu zajednicu. 


\subsubsection{Međunarodni dan biološke raznolikosti}

Međunarodni dan biološke raznolikosti, 22. svibnja, obilježili smo prigodnom izložbom i predavanjima. U predvorju Knjižnice bio je postavljen prikaz dijela izložbe Etnografskog muzeja „O životinjama i ljudima“ koju nam je predstavila jedna od kustosica. Tema izložbe bile su životinje i njihova uloga kroz povijest čovječanstva: od uloge životinja u prapovijesti, kada su dijelile prostor stanovanja s čovjekom, potom uloge životinja kao radne snage, smještanja u zoološke vrtove i cirkuse, pa do kućnih ljubimaca.

Na skupu su bila predavanja na temu biljnog i životinjskog svijeta iz različitih aspekata proučavanja kojima su se pokušale povezati znanost, prirodoslovne i ekološke teme: govorilo se o bioraznolikosti u romanima Marcela Beyera, o antropomorfizmima i zoomorfizmima u figurativnom jeziku, o životinjama u Bibliji, o okolišu i biološkoj raznolikosti u haiku poeziji, o čovjeku i okolišu u gradu Zagrebu, o biološkoj raznolikosti na Medvednici (slika 3).

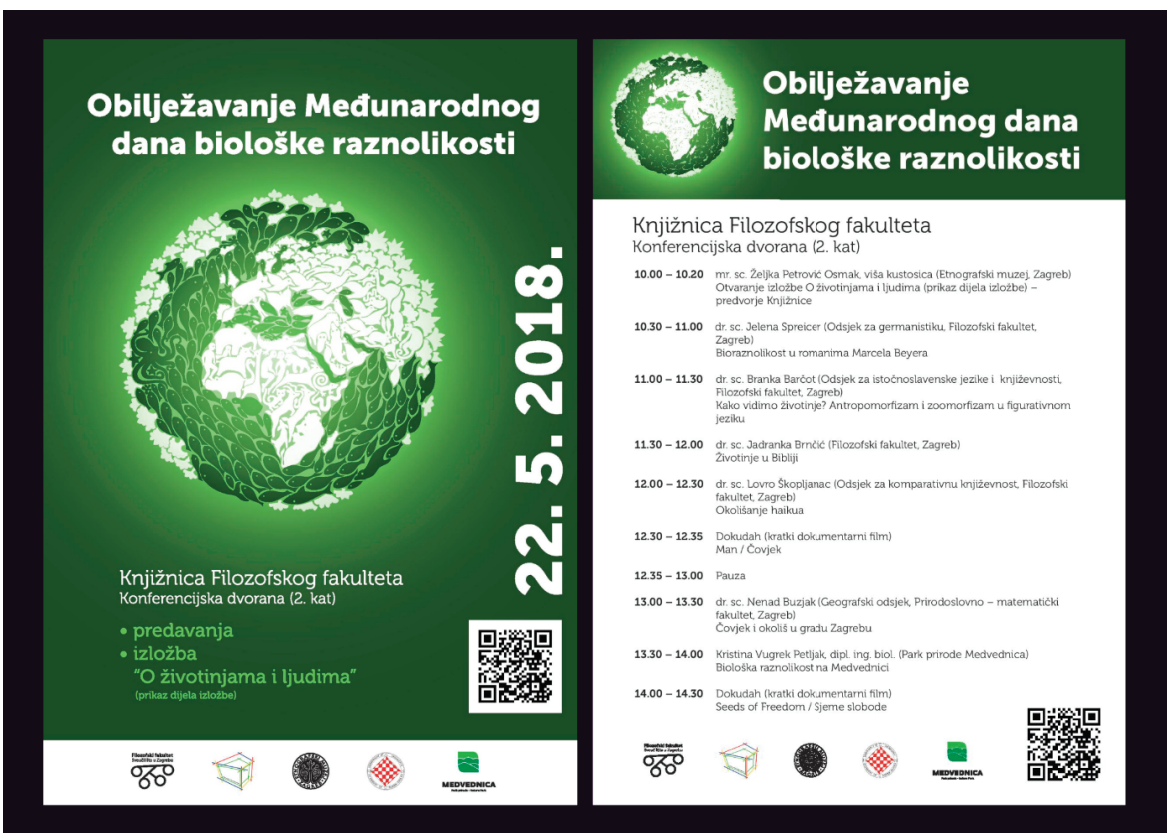

Slika 3. Plakat i program skupa organiziranog povodom Međunarodnog dana biološke raznolikosti

U suradnji s Dokudahom prikazan je kratki dokumentarni film Seeds of Freedom. Film govori o borbi između velikih korporacija, koje proizvode genetski modificirano sjeme i jedini im je interes zarada, i ljudi koji generacijama čuvaju vlastito sjeme te obrađuju zemlju da bi prehranili obitelj i lokalnu zajednicu. 


\subsubsection{Zelena biciklijada Filozofskog fakulteta}

Dana 1. 10. 2018. Knjižnica je ugostila putujuću izložbu fotografija „Cikloknjižničara“ Zagrebačkog knjižničarskog društva pod nazivom „Zelena biciklijada cikloknjižničara ZKD-a“. Pod tim je nazivom održan program organiziran u suradnji sa Zagrebačkim knjižničarskim društvom i pojedincima iz Biciklopopravljaone i Zelene akcije. Programi Cikloknjižničara organiziraju se radi povezivanja knjižnica, razmjene iskustava i unaprjeđivanja suradnje. Dodatni program sastojao se od nekoliko aktivnih sadržaja. Virtualna izložba fotografija s temom „Čistih hlača na dva kotača“ pozivala je studente da šalju fotografije na Facebook stranicu Knjižnice na temu originalnih ideja o tome kako osiguravaju rubove hlača od prljanja. Bile su organizirane i dvije izložbe, „Mini first aid kit“ i „Bicikl u knjizi“, popratna razmjena biciklističkih potrepština te dva predavanja pod nazivom „Online i knjižni resursi vezani uz servisiranje bicikala“ $i$ „Bike touring - iskustva i savjeti“. Osim toga, isti je dan organizirano popravljanje bicikala ispred zgrade Fakulteta $u$ suradnji s „Biciklopopravljaonom“ i volonterima. „Biciklopopravljaona“ je servis utemeljen na principu „uradi sam“. To znači da korisnici sami popravljaju svoje bicikle uz podršku volontera, tj. nije moguće ostaviti bicikl na popravku nego se aktivno sudjeluje u popravljanju. Velik broj studenata i zaposlenika Filozofskog fakulteta vozi bicikl, tako da je taj sadržaj bio iznimno koristan i praktičan.

\subsubsection{Održiva tribina}

Veljaču 2019. započeli smo suorganizacijom četvrte po redu održive tribine iz ciklusa Održive tribine „Let’s GO Green!“. Riječ je o tribini koju je Zelena knjižnica Filozofskog fakulteta organizirala u sklopu svojih aktivnosti „Zelena knjižnica za zelenu Hrvatsku“ te u suradnji s Radnom grupom za zelene knjižnice Hrvatskoga knjižničarskog društva. Tema tribine bile su ekološke katastrofe. Predavanja su održali predstavnici Javne ustanove Parka prirode Lonjsko polje i Javne ustanove Parka prirode Kopački rit, profesori s Prirodoslovno-matematičkog fakulteta i Farmaceutsko-biokemijskog fakulteta te Instituta Ruđer Bošković. Predavanja su se dotaknula ekologije i znanosti, vulkana, energetike te bioraznolikosti i budućnosti parkova prirode. Tom prigodom otvorena je i izložba o Lonjskom polju i Kopačkom ritu.

\subsubsection{Via Dinarica}

U svibnju 2019. bila nam je čast otvoriti izložbu „Via Dinarica - put koji prirodno povezuje“. Izložba govori o prirodnim koridorima namijenjenim planinarima, biciklistima i drugim izletnicima koji posjećuju Dinaride kao turisti, ali istodobno funkcionira kao platforma za razvoj i unaprjeđenje životnih i radnih uvjeta za autohtone stanovnike Dinarida. Osim planinarskih aktivnosti, jedan od temeljnih ciljeva projekta jest promocija lokalnog gospodarstva (turistima približiti domaću hranu, smještaj i ostale usluge). 


\subsubsection{Zeleni Dokudah}

Zbog primarne zadaće i uloge visokoškolske knjižnice, broj zelenih programa tijekom godine ograničen je, no zato se zelene teme uklapaju i u druge programe. U sklopu programa Dokudah (dokumentarni predah) prikazivali su se filmovi u suradnji s Mrežom Zelenih knjižnica i udrugom Zelena akcija koja zainteresiranim hrvatskim knjižnicama omogućuje besplatne projekcije filmova s „E-Okolišnog filmskog festivala“. Kao popratni sadržaj uz program osmišljen je i blog Dokudaha.$^{15}$ Blog je proširen kategorijom ,zeleni predah“ i poslužio je kao preporuka za dokumentarne filmove s nekom od zelenih tema. Svrha bloga višestruka je i osim što informira, uloga mu je da potiče na promišljanje i akciju. Blog je poslužio kao preporuka koja istovremeno funkcionira kao promocija audiovizualne građe i dokumentarnog filma, kao poveznica sa studentima, informacija o zelenim temama i poticaj na akciju u bližoj okolini. Koncept bloga može postati koncept obrazovanja o zelenim temama, a dokumentarni je film snažan vizualni podražaj i ishodište promjene unutar pojedinca.

\subsubsection{Zaposlenici Knjižnice Filozofskog fakulteta}

Početkom listopada 2020. godine Zelena knjižnica Filozofskog fakulteta provela je istraživanje među zaposlenicima Knjižnice radi izlaganja na stručnom skupu „Uloga knjižnica u promicanju zdravoga načina života“ 23. listopada 2020. godine u Šibeniku ${ }^{16}$, a u kojem su, između ostalog, pitani i sami zaposlenici Knjižnice jesu li slušali predavanja ili pogledali izložbe u organizaciji Zelene knjižnice Filozofskog fakulteta. Rezultat je pokazao da je 64,5 \% anketiranih zaposlenika (22 ispitanika) prisustvovalo predavanjima ili pogledalo izložbe, što govori o zainteresiranosti samih zaposlenika za zelene teme obuhvaćene organiziranim predavanjima i izložbama.

Trenutno su aktivnosti prilagođene epidemiološkoj situaciji, tako da su u planu samo tematske izložbe i virtualni stručni skup.

\subsubsection{Međunarodna prepoznatost Zelene knjižnice Filozofskog fakulteta u Zagrebu}

IFLA-ina knjižnična karta svijeta reprezentativni je izvor osnovne knjižnične statistike i robustan alat koji pruža podatke na razini države i svjetsku usporedbu različitih mjernih podataka o učinku knjižnica po regijama. Knjižnice su vodeći promotori i pružatelji besplatnog pristupa svim vrstama informacija svim građa-

15 Dokudah: dokumentarni predah. [citirano: 2021-03-19]. Dostupno na: https://Dokudah.wordpress.com.

16 Hrvatsko knjižničarsko društvo. Stručni skup s međunarodnim sudjelovanjem „Uloga knjižnica u promicanju zdravoga načina života“, 23. 10. 2020., Šibenik. [citirano: 2021-03-19]. Dostupno na: https://www.hkdrustvo.hr/hr/ispis/obavijesti/odabrana_novost/1059. 
nima. Da bi se pokazao potencijal globalnog knjižničnog polja, Knjižnična karta svijeta (Library Map of the World) sadrži sve vrste knjižnica. Početni skup mjernih podataka učinka uključuje broj knjižnica, broj knjižnica s pristupom internetu, broj osoblja i volontera, broj registriranih korisnika i posjetitelja te broj posudbi. Kao zagovarački alat, Knjižnična karta svijeta također je i platforma koja pruža pristup pričama o Ciljevima održivog razvoja (Sustainable Development Goals - SDG $)^{17}$ pokazujući kako knjižnice u različitim zemljama doprinose ciljevima održivog razvoja Ujedinjenih naroda i služe kao partneri u zadovoljavanju potreba lokalnog razvoja. ${ }^{18}$

Agenda 2030 UN-a za održivi razvoj okvir je od 17 ciljeva održivog razvoja (SDG) koji obuhvaćaju ekonomski, okolišni i socijalni razvoj, a priče pokazuju kako knjižnice i pristup informacijama pridonose poboljšanju ishoda za ciljeve održivog razvoja. ${ }^{19}$

Ciljevi održivog razvoja prikazani su na slici 4.

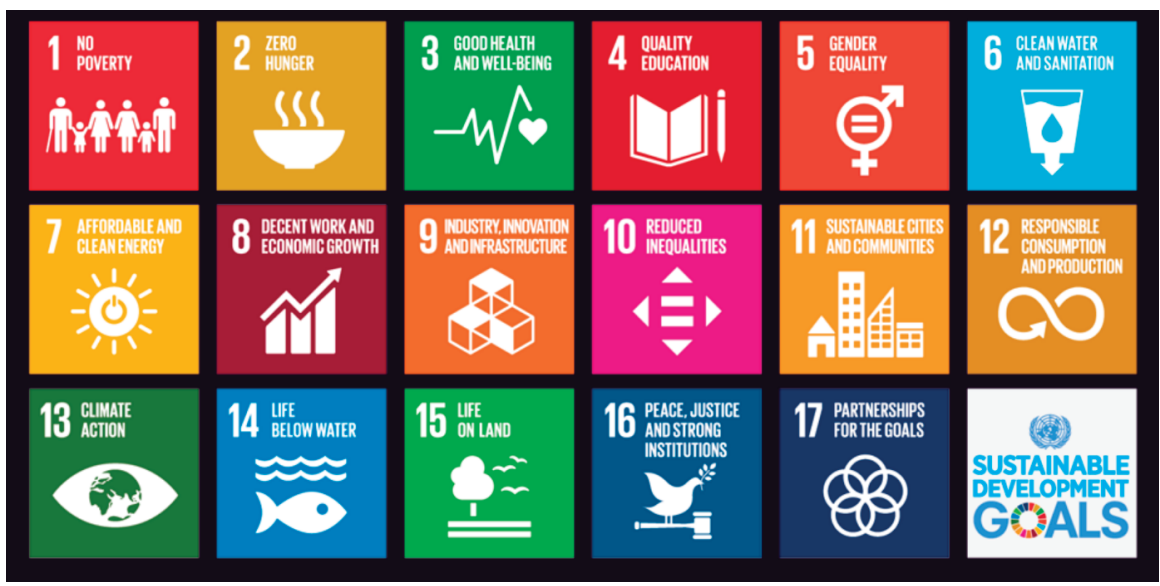

Slika 4. Ciljevi održivog razvoja ${ }^{20}$

17 Dobrovoljni nacionalni pregled o provedbi ciljeva održivog razvoja u srpnju 2019. godine u New Yorku. [citirano: 2021-05-13]. Dostupno na:

https://vlada.gov.hr/UserDocsImages/2016/Sjednice/2019/Srpanj/164\%20sjednica\%20VRH/ UN\%20Final/UN\%20-\%20zadnja\%20-\%20hrvatska\%20verzija.pdf.

18 Usp. Library Map od the World. About. [citirano: 2021-03-01]. Dostupno na: https://librarymap.ifla.org/about.

19 Usp. Library Map od the World. SDG stories. [citirano: 2021-03-01]. Dostupno na: https://librarymap.ifla.org/stories.

20 Usp. Worldview Mission. [citirano: 2021-05-20]. Dostupno na: https://worldviewmission.nl. Ciljevi su: 1. cilj: Svijet bez siromaštva; 2. cilj: Svijet bez gladi; 3. cilj: Zdravlje i blagostanje; 4. cilj: Kvalitetno obrazovanje; 5. cilj: Rodna ravnopravnost; 6. cilj: Čista voda i sanitarni uvjeti; 7. cilj: Pristupačna energija iz čistih izvora; 8. cilj: Dostojanstveni rad i ekonomski rast; 9. cilj: Industrija, inovacije i infrastruktura; 10. cilj: Smanjenje nejednakosti; 11. cilj: Održivi gradovi i zajednice; 12. cilj: Odgovorna potrošnja i proizvodnja; 13. cilj: Odgovor na klimatske promjene; 
Knjižnica Filozofskog fakulteta prva je knjižnica iz Republike Hrvatske uvrštena na IFLA-inu SDG kartu svijeta. Ciljevi održivog razvoja koji su najviše podržani dosadašnjim radom su: 6. cilj: Čista voda i sanitarni uvjeti; 12. cilj: Odgovorna potrošnja i proizvodnja; 13. cilj: Zaštita klime; 17. cilj: Partnerstvom do ciljeva.

Planiramo aktivnosti koje će tematski obraditi i ostale ciljeve UN-ove Agende 2030.

\section{Zaključak}

Društvo koje želi opstati i budućim generacijama ostaviti u nasljeđe zdravu životnu sredinu mora aktivno raditi na rješavanju izazova današnjeg načina života koji svakodnevno šteti okolišu. Knjižnice tu imaju vrlo važnu ulogu jer svojim aktivnostima informiraju i podižu svijest o važnosti održivog načina života i podučavaju o načinima kako očuvati planet na kojemu živimo i kako mu i koliko štetimo.

Knjižnica Filozofskog fakulteta u Zagrebu aktivno se od 2018. godine uključila u obrazovanje svojih korisnika, zaposlenika, a otvorena je i za sve zainteresirane za programe koje provodi na temu ekologije i očuvanja okoliša. S obzirom na to da je sastavnica visokoškolske ustanove društveno-humanističkih predmeta, uvidjela je priliku povezati se s nastavnim kadrom koji se u sklopu svojih programa dotiču zelenih tema iz različitih aspekata i u toj suradnji povezati društveno-humanističke i prirodoslovne znanosti. U spomenutim izlaganjima moglo se vidjeti koliko zapravo motiva iz prirode (voda, životinje, biljke, zrak, i dr.) nalazimo u književnosti, filozofiji, etnologiji ili umjetnosti. Iznimno je važno istaknuti suradnju koju je Knjižnica ostvarila s ustanovama, udrugama i pojedincima koji su pridonijeli kvaliteti programa te angažman samih knjižničara koji su prepoznali važnost teme i uključili se u provedbu aktivnosti. Knjižničari i svojim vlastitim primjerom, svakodnevno na poslu, pokazuju visoku ekološku osviještenost i svjesnost da kao pojedinci mogu pridonijeti globalnom nastojanju očuvanja okoliša.

Aktivnosti provedene u sklopu Zelene knjižnice Filozofskog fakulteta omogućile su bolju informiranost naših korisnika o zaštiti okoliša i održivom razvoju te povećale našu vidljivost u knjižničarskoj zajednici i u društvu.

Zelena knjižnica Filozofskog fakulteta ostvarila je dobar preduvjet integracije $\mathrm{u}$ nastavni proces s obzirom na to da ima potreban informacijski pismen kadar, prostor i tehnologiju.

14. cilj: Očuvanje vodenog svijeta; 15. cilj: Očuvanje života na Zemlji; 16. cilj: Mir, pravda i snažne institucije; 17. cilj: Partnerstvom do ciljeva. Usp.: Novi izazov: Globalni ciljevi održivog razvoja do 2030. Zagreb: ODRAZ, 2020. 7. dopunjeno izd. str. 10-26. [citirano: 2021-3-20]. Dostupno na: https://www.odraz.hr/wp-content/uploads/2021/03/GCOR_RazmisljajmoOdrzivo_Ozujak2020.pdf. 


\section{LITERATURA}

Aulisio, G. J. Green libraries are more than just buildings. // Electronic Green Journal 35, 1(2013), 1-10. [citirano: 2021-02-03].

Dostupno na: http://escholarship.org/uc/item/3x11862z.

Bačić, E. Zagovaranje za knjižnice i partnerstvo za održivi razvoj. // Vjesnik bibliotekara Hrvatske 61, 2(2018), 367-380. DOI: 10.30754/vbh.61.2.707.

Council conclusions of 26 November 2012 on Cultural Governance. // Official Journal of European Union 393(2012), 8-10. [citirano: 2021-03-10]. Dostupno na: https://eur-lex. europa.eu/legal-content/EN/TXT/PDF/?uri=CELEX:52012XG1219(03)\&from=EN.

Čadovska, I.; A. Tkalčić. Zelena pismenost kao dio strategije razvoja informacijske službe. // Vjesnik bibliotekara Hrvatske 60, 1(2017), 65-77.

DOI:10.30754/vbh.60.1.537.

Dobrovoljni nacionalni pregled o provedbi ciljeva održivog razvoja u srpnju 2019. godine u New Yorku. [citirano: 2021-13-05]. https://vlada.gov.hr/UserDocsImages/2016/Sjednice/2019/Srpanj/164\%20sjednica\%20VRH/UN\%20Final/UN\%20 -\%20zadnja\%20-\%20hrvatska\%20verzija.pdf.

Dokudah: dokumentarni predah. [citirano: 2021-03-19].

Dostupno na: https://Dokudah.wordpress.com.

Europski tjedan sporta. [citirano: 2021-03-19]. Dostupno na: https://europski-tjedan-sporta.hr/dodijeljene-becroactive-nagrade-i-svecano-uruceni-ugovori-za-projekte-financirane-iz-europskog-socijalnog-fonda.

Hrvatsko knjižničarsko društvo. 38. skupština Hrvatskoga knjižničarskog društva. [citirano: 2021-03-06]. Dostupno na: https://www.hkdrustvo.hr/hr/skupovi/skup/198.

Hrvatsko knjižničarsko društvo. 39. skupština Hrvatskoga knjižničarskog društva. [citirano: 2021-03-06]. Dostupno na: https://www.hkdrustvo.hr/hr/skupovi/skup/241.

Hrvatsko knjižničarsko društvo. Stručni skup s međunarodnim sudjelovanjem „Uloga knjižnica u promicanju zdravoga načina života“, 23. 10. 2020., Šibenik. [citirano: 2021-03-19]. Dostupno na: https://www.hkdrustvo.hr/hr/ispis/obavijesti/odabrana_novost/1059.

IFLA. Environment, sustainability and libraries section (ENSULIB). [citirano: 202103-19]. Dostupno na: https://www.ifla.org/environment-sustainability-and-libraries.

Kraljević, I. Djelovanje Radne grupe za zelene knjižnice 2014.-2018. // Vjesnik bibliotekara Hrvatske 62, 1(2019), 327-340. DOI:10.30754/vbh.62.1.720.

Library Map od the World. About. [citirano: 2021-03-01].

Dostupno na: https://librarymap.ifla.org/about.

Library Map od the World. SDG stories. [citirano: 2021-03-01].

Dostupno na: https://librarymap.ifla.org/stories. 
Library Map of the World. SDG storytelling flowchart. [citirano: 2021-03-01]. Dostupno na: https://www.ifla.org/publications/node/92032?og=7409.

Novi izazov: Globalni ciljevi održivog razvoja do 2030. Zagreb: ODRAZ, 2020. 7. dopunjeno izd. [citirano: 2021-3-20]. Dostupno na: https://www.odraz.hr/wp-content/ uploads/2021/03/GCOR_RazmisljajmoOdrzivo_Ozujak2020.pdf.

Okolišni filmski festival. [citirano: 2021-03-19].

Dostupno na: https://okolisnifestival.zelena-akcija.hr/o-festivalu.

Strategija održivog razvitka Republike Hrvatske. // Narodne novine 30, 658(2009). [citirano: 2021-05-20].

Dostupno na: http://narodne-novine.nn.hr/clanci/sluzbeni/2009_03_30_658.html.

UN. Transforming our world: The 2030 agenda for sustainable development, 2015. [citirano: 2021-03-10].

Dostupno na: https://www.un.org/ga/search/view_doc.asp?symbol=A/RE$\mathrm{S} / 70 / 1 \&$ Lang $=\mathrm{E}$.

Worldview Mission. [citirano: 2021-05-20]. Dostupno na: https://worldviewmission.nl.

Zakon o knjižnicama. // Narodne novine 17, 356(2019). [citirano: 2021-3-3]. Dostupno na: https://narodne-novine.nn.hr/clanci/sluzbeni/2019_02_17_356.html.

Zelena knjižnica. // Društvo bibliotekara Istre, 2011. [citirano: 2021-03-19].

Dostupno na: http://zk.dbi.hr. 